\title{
Distribusi Spasial Kerapatan Mangrove Menggunakan Citra Sentinel-2A Di TAHURA Ngurah Rai Bali
}

\author{
I Gede Merta Yoga Pratama a,b*, I Wayan Gede Astawa Karang a,b, Yulianto Suteja ${ }^{a}$ \\ a Program Studi Ilmu Kelautan, Fakultas Kelautan dan Perikanan, Universitas Udayana, Kampus UNUD Bukit Jimbaran, Bali 80361, Indonesia \\ ${ }^{b}$ Laboratorium Remote Sensing dan GIS, Fakultas Kelautan dan Perikanan, Universitas Udayana, Kampus UNUD Bukit Jimbaran, Bali 80361, \\ Indonesia \\ * Penulis koresponden. Tel.: +62-821-4413-6749 \\ Alamat e-mail: mypratama96@gmail.com
}

Diterima (received) 15 Juli 2018; disetujui (accepted) 14 Januari 2019; tersedia secara online (available online) 15 Januari 2019

\begin{abstract}
The mangrove forest of TAHURA Ngurah Rai is one of the mangrove ecosystems in Bali that suffered damages and density changes due to natural factors and human activities. Remote sensing is one of the technology that can be used to estimate the density of mangrove canopy in TAHURA Ngurah Rai. The purpose of this study was to find the best vegetation index for estimating mangrove canopy density out and map it spatially using Sentinel-2A image. The method of this research is using vegetation index NDVI, EVI and mRE-SR to estimate mangrove canopy density. Field data was collected using Stratified Random and Proportional Sampling method by taking photo of the density of canopy using camera with Fish Eye lens on 34 plot. The results of this study show the satistic test of the linear model of the vegetation index with the mangrove canopy density value on the NDVI index $\left(r=0.8165, R^{2}=0.6667, \mathrm{RMSE}= \pm 8.1508\right)$, $\operatorname{EVI}\left(r=0.8597, R^{2}=0.7390, \operatorname{RMSE}= \pm 7.8117\right)$, and mRE-SR $\left(r=0.9277, R^{2}=0.8607, \mathrm{RMSE}= \pm 4.9571\right)$. The conclusion of this research is mRE-SR vegetation index able to map mangrove canopy density better than NDVI and EVI vegetation index with $86.07 \%$ accuracy. The mangrove spatial distribution generated from the mRE-SR model is $1002.22 \mathrm{Ha}$ with 3.24 Ha categorized as very high density, 94.82 Ha categorized as high density, 333 Ha categorized as medium density, 402.38 Ha categorized as low density, and categorized as very low density is up to 168.76 Ha.
\end{abstract}

Keywords: mangrove canopy; density; vegetation index

\begin{abstract}
Abstrak
Hutan mangrove TAHURA Ngurah Rai merupakan salah satu ekosistem mangrove di Bali yang mengalami kerusakan dan perubahan kerapatan karena faktor alam dan aktivitas manusia. Penginderaan jauh adalah salah satu teknologi yang dapat digunakan untuk estimasi kerapatan tajuk mangrove TAHURA Ngurah Rai. Tujuan dari penelitian ini adalah untuk mengetahui indeks vegetasi terbaik dalam mengestimasi kerapatan tajuk mangrove dan memetakannya secara spasial menggunakan citra Sentinel-2A. Metode penelitian ini adalah menggunakan indeks vegetasi NDVI, EVI dan mRE-SR untuk estimasi kerapatan tajuk mangrove. Pengambilan data lapangan dilakukan menggunakan metode Stratified Random dan Proporsional Sampling dengan mengambil foto kerapatan tajuk menggunakan kamera dengan lensa Fish Eye pada 34 plot. Hasil penelitian ini menunjukkan uji satistik dari model linier indeks vegetasi dengan nilai kerapatan tajuk mangrove pada indeks NDVI $\left(r=0.8165, \mathrm{R}^{2}=0.6667, \mathrm{RMSE}= \pm 8.1508\right), \mathrm{EVI}\left(\mathrm{r}=0.8597, \mathrm{R}^{2}=0.7390\right.$, RMSE $= \pm 7.8117)$, dan mRE-SR $\left(r=0.9277, R^{2}=0.8607\right.$, RMSE $\left.= \pm 4.9571\right)$. Kesimpulan dari penelitian ini adalah indeks vegetasi mRE-SR mampu memetakan kerapatan tajuk mangrove lebih baik dari indeks vegetasi NDVI dan EVI dengan akurasi mencapai 86.07 \%. Distribusi spasial mangrove yang dihasilkan dari model mRE-SR adalah seluas 1002.22 Ha dengan kerapatan tajuk kategori sangat rapat adalah 3.24 Ha, kerapatan tajuk kerapatan tajuk kategori rapat seluas $94.82 \mathrm{Ha}$, kerapatan sedang seluas $333 \mathrm{Ha}$, kerapatan jarang seluas 402.38 Ha dan kategori kerapatan sangat jarang seluas $168.78 \mathrm{Ha}$.
\end{abstract}

Kata Kunci: tajuk mangrove; kerapatan; indeks vegetasi 


\section{Pendahuluan}

Hutan mangrove merupakan salah satu ekosistem penting di kawasan pesisir. Luas hutan mangrove di Indonesia tahun 2010 seluas 3.112.989 ha atau $22,6 \%$ dari luasan mangrove dunia sehingga menjadikan Indonesia sebagai negara pemilik hutan mangrove terluas (Giri et al., 2011). Dewasa ini hutan mangrove banyak yang mengalami kerusakan atau degradasi karena aktivitas antropogenik seperti penebangan liar, konversi lahan mangrove, pembangunan di kawasan pesisir disertai polusi yang berasal dari daratan (Samsoedin dkk, 2009).

Provinsi Bali merupakan salah satu provinsi yang memiliki perkembangan aktivitas manusia yang cukup signifikan. Provinsi Bali bersama dengan Kepulauan Nusa Tenggara memiliki persentase luasan dan kerapatan hutan yang terdeforestasi paling besar nomor dua setelah Pulau Jawa dengan angka $45.92 \%$. Hutan mangrove di Provinsi Bali tersebar di tiga lokasi terluas yaitu Taman Hutan Raya (TAHURA) Ngurah Rai (1373,5 Ha), Nusa Lembongan (202 Ha), dan Taman Nasional Bali Barat (602 Ha). Apabila tidak diimbangi dengan kebijakan pengelolaan yang tepat, fenomena degradasi luasan dan kerapatan mangrove akan terus terjadi. Sehingga perlu dilakukan kajian mengenai kondisi kerapatan mangrove, salah satunya kawasan hutan mangrove di Bali yaitu Taman Hutan Raya (Tahura) Ngurah Rai Bali.

Kerapatan mangrove dapat diketahui melalui pengukuran langsung ke lapangan dan dengan penginderaan jauh (Kresnabayu dkk, 2009). Metode pengukuran kerapatan secara langsung ke lapangan menghasilkan akurasi yang tinggi akan tetapi apabila dilakukan pada kawasan mangrove yang luas maka menjadi tidak efektif dan efisien dari segi waktu dan biaya (Hirata et al., 2014). Penginderaan jauh menjadi alternatif solusi metode estimasi kerapatan di atas permukaan hutan mangrove secara spasial. Mengkombinasikan data dari survei lapangan dengan data penginderaan jauh dianggap metode yang ideal dan praktis untuk melihat distribusi spasial kerapatan Mangrove (Heumann, 2011).

Pemanfaatan data penginderaan jauh untuk estimasi kerapatan mangrove di TAHURA Ngurah Rai pernah dilakukan dengan citra Landsat TM, ETM+, dan 8 OLI/TIRS oleh Nuarsa et al., (2005), Sugianthi et al., (2012) dan Karang dkk. (2015).
Penelitian tersebut menghasilkan estimasi kerapatan mangrove dengan koefisien determinasi pada rentang $47.08 \%$ hingga $63.12 \%$. Hasil tersebut diperoleh karena resolusi spasial dari citra Landsat yang tergolong rendah dan perbedaan rentang waktu citra dengan pengambilan data di lapangan. Penggunaan resolusi citra yang berbeda menghasilkan akurasi model yang berbeda pula. Citra resolusi spasial tinggi memiliki kesempatan untuk memetakan kerapatan mangrove lebih detail (Ni-Meister et al., 2010). Salah satu satelit dengan resolusi spasial tinggi adalah Sentinel-2A.

Satelit Sentinel-2A dilengkapi dengan instrumen multispektral 13 saluran spektral dengan resolusi spasial 10 meter. Berbagai macam transformasi spektral dari citra Sentinel-2A dapat digunakan untuk mengetahui estimasi kerapatan mangrove. Transformasi citra yang paling umum dan banyak digunakan untuk pemetaan dan pemodelan mangrove adalah indeks vegetasi (Wicaksono et al., 2016). Setiap indeks vegetasi menghasilkan nilai akurasi yang berbeda terhadap nilai kerapatan mangrove (Mitra et al., 2011). Banyaknya algoritma dalam penentuan kerapatan tajuk tentunya merupakan tantangan tersendiri bagi peneliti untuk mengetahui sejauh mana suatu indeks vegetasi dapat menyajikan informasi vegetasi secara tepat. Penelitian ini menggunakan indeks Normalized Difference Vegetation Index (NDVI), Enhanced Vegetation Index (EVI), dan Modified Red Edge-Simple Ratio (mRE-SR). Tujuan dari penelitian ini adalah untuk mengetahui indeks vegetasi terbaik dalam menjelaskan kerapatan tajuk mangrove dari indeks NDVI, EVI, dan mRE-SR serta mengetahui distribusi spasial kerapatan mangrove di TAHURA Ngurah Rai.

\section{Metode Penelitian}

\subsection{Waktu dan Lokasi Penelitian}

Lokasi penelitian ini dilakukan di wilayah mangrove TAHURA Ngurah Rai yang terletak di wilayah Kecamatan Kuta dan Kuta Selatan Kabupaten Badung, dan Pulau Serangan Kecamatan Denpasar Selatan Kota Denpasar dengan koordinat $08^{0} 41^{\prime}-08^{\circ} 47^{\prime}$ LS dan 115010'$115^{0} 15^{\prime}$ BT (Gambar 1). Waktu pengambilan sampel foto kerapatan tajuk dilakukan pada tanggal 12 dan 20 Maret 2018. Pengolahan data dilakukan di Laboratorium Remote Sensing dan GIS Fakultas Kelautan dan Perikanan, Universitas Udayana. 


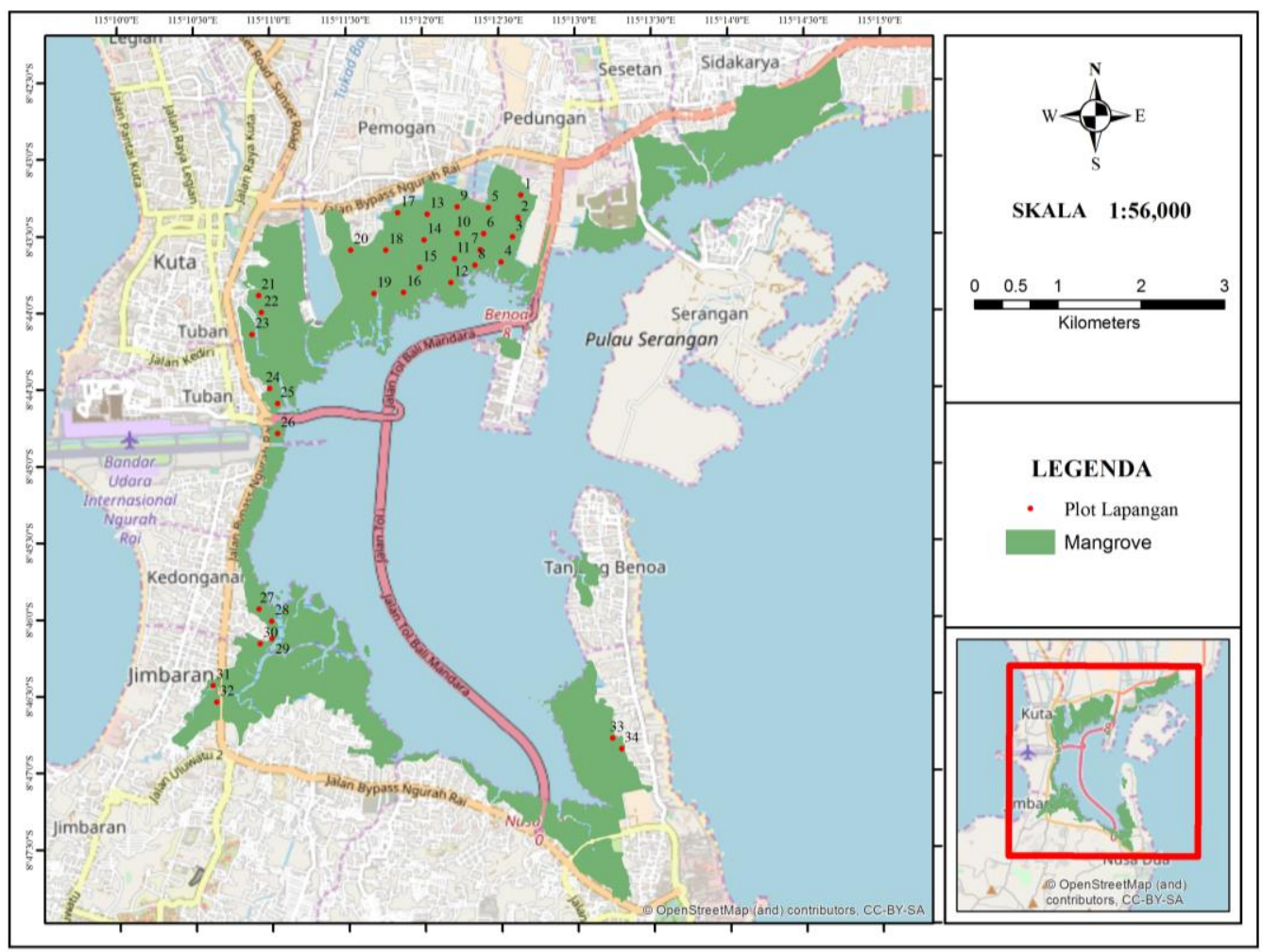

Gambar 1. Plot pengambilan data insitu berupa foto kerapatan tajuk mangrove di TAHURA Ngurah Rai.

\subsection{Tahap Penelitian}

\subsubsection{Pra Pengolahan Citra}

Citra yang digunakan adalah citra Sentinel-2A level 1C dengan akuisisi tanggal 8 Maret 2018 sebagai pembangun model dan 17 Juni 2018 untuk validasi model. Pra pengolahan citra merupakan langkah awal dalam pengolahan citra satelit. Tahapan pra pengolahan citra dilakukan pada software QGIS versi 2.4 dengan plugin Semi-Automatic Classification yang meliputi proses koreksi atmosferik, pemotongan citra (cropping), dan resampling citra. Metode Dark Object Subtraction (DOS) digunakan dalam proses koreksi atmosferik untuk mengurangi gangguan dari atmosfer dan memperjelas dalam mengenali objek saat diinterpretasikan. Piksel yang telah terkoreksi akan ditampilkan dalam nilai reflectance. Pemotongan citra atau biasa disebut cropping dilakukan untuk mempersempit daerah penelitian dan juga memperkecil ukuran file dari citra agar mempercepat proses pengolahan pada software. Tahap terakhir adalah resampling citra dengan metode Nearest Neighbor. Resampling citra dilakukan untuk mengubah resolusi spasial band $R E D$-Edge yang semula 20 meter menjadi 10 meter.

\subsubsection{Pengolahan Citra}

Citra Sentinel-2A yang telah terkoreksi selanjutnya diolah melalui tahap Penyusunan Citra Komposit, Masking, dan Transformasi Spektral. Kombinasi RGB 432 (True Color) adalah komposit citra yang digunakan dalam penelitian ini. Pengolahan dilakukan pada software SNAP versi 5.0 dengan menggunakan kanal merah untuk saluran 4 (band 4: $665 \mathrm{~nm}$ ), kanal hijau pada saluran 3 (band 3: 560 $\mathrm{nm}$ ) dan kanal biru pada saluran 2 (band 2: $490 \mathrm{~nm}$ ) yang digunakan untuk mengidentifikasi obyek hutan mangrove (Utami dkk, 2016).

Masking adalah proses pemisahan antara daerah kajian dengan dengan wilayah yang tidak termasuk pengamatan. Nilai piksel wilayah darat diubah menjadi nol (0) menggunakan software SNAP dan diperhalus dengan shapefile dari Open Street Map agar proses klasifikasi tidak dipengaruhi oleh nilai dari daratan. Tahap terakhir adalah transformasi spectral dengan menggunakan tool Band Calculator pada software QGIS. Rumus transformasi spektral dari indeks vegetasi NDVI, EVI, dan mRE-SR setelah disesuaikan dengan band sentinel 2A dapat dilihat pada persamaan (1), (2), dan (3). 


$$
N D V I=\frac{N I R-R E D}{N I R+R E D}
$$

dimana NIR adalah band Band 8; RED adalah Band 4 pada citra Sentinel-2A (Aji dan Prasetyo, 2017)

$$
E V I=G \frac{N I R-R E D}{N I R+C 1 R E D-C 2 B L U E+L}
$$

dimana NIR adalah band Band 8; RED adalah Band 4; BLUE adalah Band 2 pada citra Sentinel-2A. G adalah adalah faktor gain dengan nilai 2.5; $\mathrm{C} 1$ dan C2 adalah adalah koefisien resistansi aerosol pada saluran merah dan biru dengan nilai masingmasing 6.0 dan 7.5; nilai L berfungsi sebagai soiladjustment faktor dengan nilai 1 (Frananda dkk. 2015)

$$
m R E-S R=\frac{\left(\frac{N I R}{R E D E d g e}\right)-1}{\sqrt{\left(\frac{N I R}{R E D E d g e}\right)+1}}
$$

dimana NIR adalah Band 8; RED Edge adalah Band 5 pada citra Sentinel-2A (Candra et al., 2016).

\subsubsection{Pengambilan Data Lapangan}

Penentuan sampel di lapangan menggunakan metode stratified random dan proporsional sampling (BIG, 2014). Pada penelitian ini, digunakan plot dengan ukuran $10 \mathrm{~m} \times 10 \mathrm{~m}$ dari tali plastik sepanjang 100 meter. Desain pengamatan lapangan dengan sampel plot dapat dilihat pada Gambar 2. Titik hitam di setiap sudut dan bagian tengah menunjukkan titik pengambilan data kerapatan mangrove. Kerapatan mangrove yang diukur pada penelitian ini adalah kerapatan tajuk.

Kerapatan tajuk mangrove diukur dengan mengambil foto vertikal menggunakan kamera dengan lensa Fish Eye di lima titik pada setiap plot untuk melihat keseluruhan bagian tumbuhan, terutama pohon, perdu, atau liana, yang berada di atas permukaan tanah yang menempel pada batang utama. Foto yang diperoleh kemudian dibuka pada aplikasi ImageJ untuk mengubah foto menjadi Image 8 bit dengan nilai piksel maksimun 255 (P255). Perhitungan persentase kerapatan tajuk menurut Dharmawan dan Pradmuji (2014) dapat dilihat pada persamaan (8).
Persentase Kerapatan Tajuk $=\frac{P 255}{\sum P} \times 100 \%$

dimana P255 adalah nilai piksel yang mewakili tajuk; dan $\sum P$ adalah

Nilai persentase di 5 titik pada satu plot dirataratakan sehingga menghasilkan nilai persentase per plot. Nilai dari kerapatan tersebut selanjutnya diklasifikasikan menjadi 5 kelas yaitu mangrove sangat rapat, mangrove rapat, mangrove sedang, mangrove jarang, mangrove sangat jarang. Penentuan interval antar kelas kerapatan tajuk dilakukan dengan mencari selisih nilai kerapatan tertinggi dengan nilai kerapatan terendah kemudian dibagi dengan jumlah kategori yang diinginkan (BIG, 2014). Jumlah piksel dari masingmasing kelas kerapatan tajuk selanjutnya dihitung menggunakan tools Grid Calculator pada software SAGA GIS untuk memperoleh luasan dari setiap kelas tersebut.

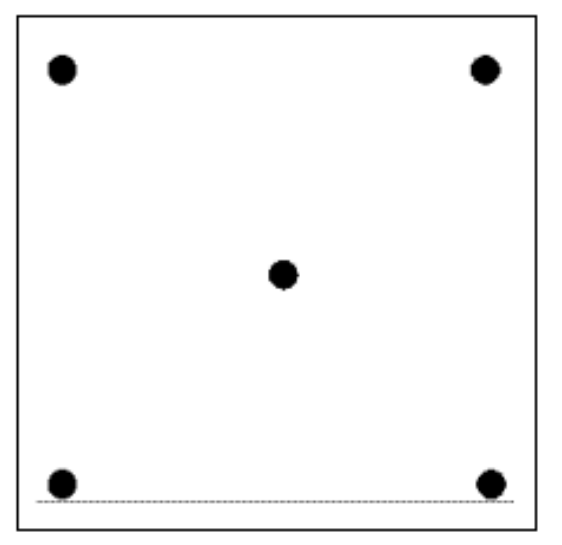

Gambar 2. Plot pengambilan data kerapatan tajuk di lapangan.

\subsection{Analisis Data}

\subsubsection{Analisis Regresi Linier}

Koefisien regresi merupakan koefisien yang mengukur besarnya pengaruh (X) nilai indeks vegetasi terhadap peubah terikat $(\mathrm{Y})$ nilai kerapatan tajuk dalam model persamaan regresi linier. Analisis regresi linier pada penelitian ini digunakan untuk membangun model linier dari indeks vegetasi terhadap nilai kerapatan mangrove dari 34 plot di lapangan. Bentuk persamaan regresi menurut Mairing (2017) dapat dilihat pada persamaan (5) 


$$
Y=a+b X
$$

$$
b=\frac{n\left(\sum x y\right)-\left(\sum x\right) \cdot\left(\sum y\right)}{n\left(\sum x^{2}\right)-\left(\sum x\right)^{2}} a+b X
$$

$$
a=\frac{\sum y-b \cdot\left(\sum x\right)}{n}
$$

dimana $X$ adalah nilai indeks vegetasi; $Y$ adalah nilai kerapatan tajuk mangrove; $a$ adalah konstanta, $b$ adalah koefisien regresi; $n$ adalah jumlah data.

\subsubsection{Uji Korelasi}

Koefisien korelasi ( $r$ ) dilakukan untuk mengetahui kekuatan hubungan antara nilai indeks vegetasi dengan nilai kerapatan tajuk mangrove dari perhitungan lapangan. Adapun rumus korelasi sederhana menurut Mairing (2017) dapat dilihat pada persamaan (8)

$$
r=\frac{\sum x y-\frac{\left(\sum x\right)\left(\sum y\right)}{n}}{\sqrt{\left(\sum x^{2}-\frac{\left(\sum x\right)^{2}}{n}\right)\left(\sum y^{2}-\frac{\left(\sum y^{2}\right)}{n}\right)}}
$$

dimana $X$ adalah variabel bebas (nilai indeks vegetasi); $Y$ adalah variabel terikat (nilai kerapatan tajuk mangrove); $a$ adalah konstanta, $b$ adalah koefisien regresi; $n$ adalah jumlah data.

\subsubsection{Uji Koefisien Determinasi}

Koefisien determinasi $\left(\mathrm{R}^{2}\right)$ pada penelitian ini digunakan untuk mengetahui seberapa baik kemampuan model regresi linier indeks vegetasi dalam menjelaskan variasi kerapatan tajuk mangrove di lapangan. Rentang nilai koefisien determinasi berada diantara 0 hingga 1 . Nilai $R^{2}$ yang rendah menunjukkan kemampuan model linier dalam menjelaskan variasi kerapatan tajuk amat terbatas. Nilai koefisien selanjutnya diubah ke dalam bentuk persentase menurut Mairing (2017) ditunjukkan pada persamaan (9)

$$
R^{2}=\frac{\left((n)\left(\sum x y\right)-\left(\sum x\right)\left(\sum y\right)\right)^{2}}{\left(n\left(\sum x^{2}\right)-\left(\sum x\right)^{2}\left(n\left(\sum y^{2}\right)-\left(\sum y\right)^{2}\right)\right)}
$$

dimana $X$ adalah variabel bebas (nilai indeks vegetasi); $Y$ adalah variabel terikat (nilai kerapatan tajuk mangrove); $n$ adalah jumlah data

\subsubsection{Uji Validasi Model}

Uji validasi dilakukan untuk mengetahui penyimpangan nilai penduga kerapatan mangrove hasil dari model-model regresi yang dibangun dengan kerapatan tajuk di lapangan. Validasi model dilakukan dengan cara membandingkan nilai kerapatan tajuk dari 34 plot di lapangan dengan persamaan model linier setiap indeks yang di aplikasikan pada citra Sentinel-2A tanggal akuisisi 17 Juni 2018. Uji validasi model terbangun dengan menggunakan RMSE (Root Mean Square Error). Perhitungan RMSE menurut Mairing (2017) dapat dilihat pada persamaan (10).

$$
R M S E=\frac{\sqrt{\sum(E-O)^{2}}}{n}
$$

dimana $E$ adalah nilai dugaan; $O$ adalah nilai aktual; dan $n$ adalah jumlah data keseluruhan.

\section{Hasil dan Pembahasan}

\subsection{Nilai Indeks Vegetasi}

Hasil transformasi spektral citra satelit Sentinel-2A diperoleh nilai indeks vegetasi berupa NDVI, EVI, dan mRE-SR. Nilai indeks NDVI yang dihasilkan dari penelitian ini berada pada rentang 0.5 hingga 0.905157. Penelitian Kresnabayu dkk. (2018) menghasilkan nilai NDVI pada rentang $0.4-0.8$ pada kawasan mangrove di Estuari Perancak. Penelitian Sugianthi et al. (2012) menggunakan citra Landsat TM dan ETM+ menunjukkan nilai NDVI di kawasan mangrove TAHURA Ngurah Rai berada pada rentang nilai 0.46 hingga 0.87 . Kawamuna dkk. (2017) menggunakan citra Sentinel-2A untuk menganalisis kesehatan mangrove di kawasan mangrove Teluk Pangpang Kabupaten Banyuwangi menghasilkan nilai NDVI sebesar 0.119 hingga 0.811 . Nilai NDVI yang tinggi dari hasil penelitian ini menunjukkan proses pemantulan maksimum gelombang Near Infrared dan penyerapan maksimum gelombang Visible Red terjadi karena struktur daun (mesophyll) yang rapat di kawasan Tahura Ngurah Rai (As-syakur dan Adnyana, 2009). Hal tersebut sesuai dengan pernyataan Muhsoni (2009) mengatakan nilai indeks NDVI yang mendekati 1 menunjukkan semakin rapat vegetasi pada obyek tersebut.

Nilai indeks EVI yang dihasilkan dari penelitian ini berada pada nilai 0.250011 hingga 0.63335 . 
Rentang nilai indeks EVI berada pada nilai -1 hingga +1 (Hatfield and Prueger, 2010). Penelitian Kustandiyo dkk. (2015) menunjukkan nilai kawasan mangrove di kawasan Cilacap, Jawa Tengah menggunakan citra Landsat TM dari indeks EVI berada pada rentang nilai -0.003 hingga 0.639 . Nilai indeks yang lebih besar dari 0.1 menandakan peningkatan derajat kehijauan dan intensitas dari vegetasi (Sudiana dan Diasmara 2008). Nilai indeks EVI pada penelitian ini lebih tinggi dari 0.1 yang menunjukkan nilai kehijauan dari vegetasi mangrove dapat terekam secara maksimal karena indeks vegetasi EVI lebih tahan terhadap gangguan warna tanah serta mampu mengurangi gangguan dari awan (Fensholt et al., 2006).

Hasil dari indeks mRE-SR menunjukkan mangrove TAHURA Ngurah Rai memiliki nilai indeks mRE-SR pada rentang 0.87003 hingga 2.06614. Indeks Vegetasi mRE-SR merupakan indeks yang dikembangkan dari indeks SR (Simple Ratio). Suyadi dkk. (2013) menunjukkan indeks SR di kawasan mangrove Gugus Pulau Pari, Kepulauan Seribu dari satelit ALOS AVNIR-2 berada pada rentang 0.84 hingga 1.72. Pada formula indeks mRE-SR, band Visible Red dimodifikasi dengan mengganti band tersebut dengan band RED-Edge (Merah Tepi) pada panjang gelombang $705 \mathrm{~nm}$. Band RED-Edge diketahui lebih sensitif terhadap parameter biofisik seperti kerapatan vegetasi dibandingkan dengan band-band lainnya sehingga penggunaan band ini menghasilkan nilai indeks lebih besar dari indeks vegetasi lainnya (Zhu et al., 2017).

\subsection{Pemilihan Model Terbaik}

Ketiga indeks vegetasi pada penelitian ini menghasilkan nilai indeks yang beragam terhadap nilai kerapatan tajuk di lapangan. Indeks terbaik untuk mengestimasi kerapatan tajuk diperoleh dari model regresi linier dari masing-masing indeks. Hasil uji model linier masing-masing indeks dapat dilihat pada Tabel 1.

\subsubsection{Model Linier NDVI}

Hasil model regresi linier yang dihasilkan dari indeks NDVI adalah Y = 174.93X - 69.02 (Gambar 3). Korelasi di antara dua variabel tersebut adalah 0.8165. Hasil korelasi tersebut menunjukkan hubungan positif menyatakan hubungan kuat dimana semakin besar nilai indeks NDVI maka diikuti pula perubahan dengan semakin besar nilai persentase kerapatan tajuk mangrove (Kusumaningrum dan Sukojo, 2013)

Tabel 1

Hasil Uji Model Regresi Linier Kerapatan Tajuk Mangrove.

\begin{tabular}{ccccc}
\hline $\begin{array}{c}\text { Indeks } \\
\text { Vegetasi }\end{array}$ & $\begin{array}{c}\text { Regresi } \\
\text { Linier }\end{array}$ & $\mathrm{r}$ & $\mathrm{R}^{2}$ & $\mathrm{RMSE}$ \\
\hline \multirow{5}{*}{$\mathrm{Y}=174.93 \mathrm{X}$} & & & \\
NDVI & $\begin{array}{l}-69.02 \\
\mathrm{Y}\end{array}$ & 0.8165 & 0.6667 & 8.1508 \\
& $+130.25 \mathrm{X}$ & & & \\
EVI & +12.18 & 0.8597 & 0.7390 & 7.8117 \\
& $\mathrm{Y}=49.08 \mathrm{X}+$ & & & \\
mRE-SR & 5.391 & 0.9277 & 0.8607 & 4.9571 \\
\hline
\end{tabular}

Hasil uji koefisien determinasi $\left(\mathrm{R}^{2}\right)$ pada indeks vegetasi NDVI adalah 0.6667 yang berarti sebesar $66,67 \%$ variasi nilai kerapatan tajuk mangrove di lapangan dapat dijelaskan oleh nilai piksel dari indeks vegetasi NDVI. Nilai $R^{2}$ tersebut menyerupai hasil dari penelitian sebelumnya yang dilakukan oleh Sugianthi et al., (2012) dengan hasil $\mathrm{R}^{2}$ sebesar 0.6312 yang berarti sebanyak $63.12 \%$ dari citra Landsat TM di TAHURA Ngurah Rai. Hasil tersebut menunjukkan indeks NDVI dari Citra Sentinel-2A mampu menjelaskan nilai kerapatan tajuk lebih baik dibandingkan dengan citra Landsat ETM+. Hal tersebut terjadi diduga karena resolusi spasial dari citra Sentinel-2A (10 meter) yang lebih tinggi dari Landsat ETM+ (30 meter). Citra resolusi spasial tinggi memiliki kesempatan untuk memetakan kerapatan mangrove lebih detail (NiMeister et al., 2010)

Hasil uji RMSE untuk indeks vegetasi NDVI sebesar 8.1508 yang artinya penyimpangan nilai penduga kerapatan mangrove hasil dari model regresi yang dibangun adalah sebesar $\pm 8.1508 \%$ terhadap nilai perhitungan kerapatan tajuk di lapangan. Nilai RMSE dari masing-masing model pada Tabel 1 menunjukkan indeks vegetasi NDVI sebagai indeks dengan nilai penyimpangan terhadap nilai aktual di lapangan terbesar. Hal tersebut diduga disebabkan oleh kelemahan dari indeks NDVI seperti noise karena gangguan atmosfer dan faktor latar belakang berupa tanah (Candra et al., 2016). Sinaga dkk. (2018) mengatakan adanya gangguan atmosfer membuat nilai indeks NDVI menurun sedangkan aerosol yang berukuran kecil meningkatkan nilai indeks NDVI, sehingga pada penelitian ini nilai persentase kerapatan tajuk 
dari indeks vegetasi NDVI menghasilkan penyimpangan terbesar dibanding indeks lainnya.

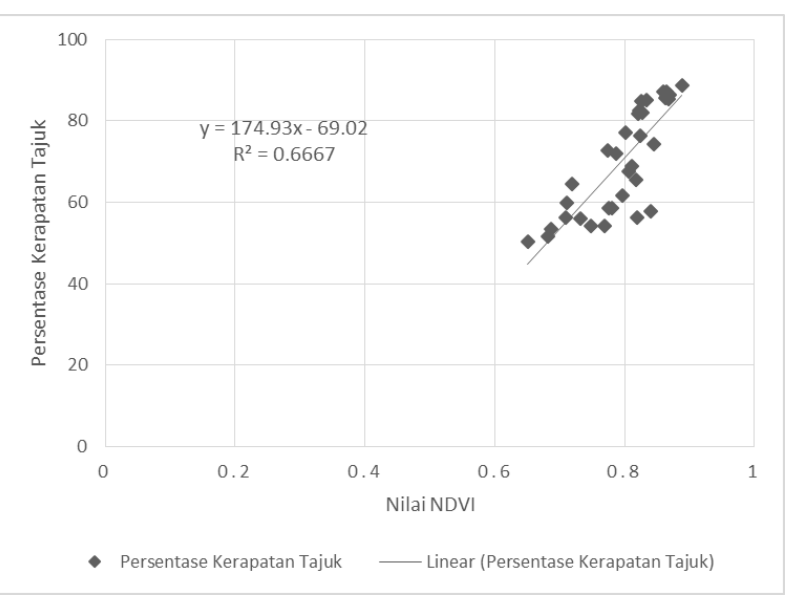

Gambar 3. Hasil regresi linier Indeks Vegetasi NDVI

\subsubsection{Model Linier EVI}

Hasil model regresi linier yang dihasilkan dari indeks vegetasi EVI dengan nilai persentase kerapatan tajuk mangrove adalah $\mathrm{Y}=130.25 \mathrm{X}+$ 12.18 (Gambar 4). Korelasi diantara dua variabel tersebut adalah 0.8597 yang menunjukkan hubungan positif dan kuat dimana semakin besar nilai indeks EVI maka diikuti pula perubahan dengan semakin besar nilai kerapatan tajuk.

Nilai koefisien determinasi $\left(\mathrm{R}^{2}\right)$ yang dihasilkan dari model regresi tersebut adalah 0.739 yang berarti bahwa sebanyak $73,9 \%$ variasi nilai persentase kerapatan tajuk mangrove di lapangan dapat dijelaskan oleh nilai piksel dari indeks vegetasi EVI. Hasil tersebut menunjukkan model regresi linier EVI mampu menjelaskan kerapatan tajuk mangrove aktual dilapangan lebih baik dibandingkan dengan indeks NDVI. Hal tersebut terjadi karena Indeks EVI memiliki keunggulan dari indeks NDVI yaitu memiliki faktor penyesuaian latar belakang tanah dan koefisien untuk mengkoreksi hamburan atmosfer (Candra et al., 2016). Sudiana dan Diasmara (2008) menyatakan kelebihan lain dari algoritma EVI yaitu menghasilkan sensitifitas yang lebih tinggi terhadap vegetasi yang subur dan lebat serta meminimalisasi gangguan atmosfir pada data satelit. Hasil uji RMSE menunjukkan penyimpangan nilai penduga kerapatan mangrove hasil dari model regresi EVI yang dibangun adalah sebesar 7.8117. Nilai tersebut menunjukkan penyimpangan hasil model terhadap nilai kerapatan tajuk adalah $\pm 7.8117 \%$ dari nilai persentase kerapatan tajuk hasil perhitungan lapangan. Nilai RMSE ini lebih kecil dari nilai RMSE indeks NDVI sehingga model indeks EVI dapat dikatakan lebih baik dari model indeks NDVI dalam memetakan kerapatan tajuk mangrove.

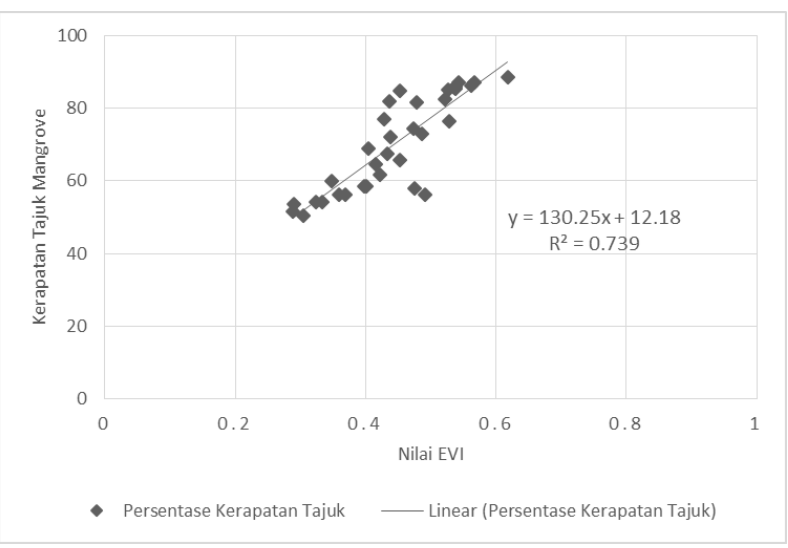

Gambar 4. Hasil regresi linier Indeks Vegetasi EVI

\subsubsection{Model Linier mRE-SR}

Hasil regresi linier yang dihasilkan dari indeks mRE-SR dengan nilai persentase kerapatan tajuk mangrove adalah $Y=49.08 X+5.391$ (Gambar 5). Korelasi diantara dua variabel tersebut adalah 0.9277 yang menunjukkan hubungan positif dan kuat. Korelasi dari nilai indeks mRE-SR dengan nilai kerapatan tajuk mangrove tersebut merupakan nilai korelasi terbesar dibandingkan nilai korelasi indeks NDVI dan EVI (Tabel 1).

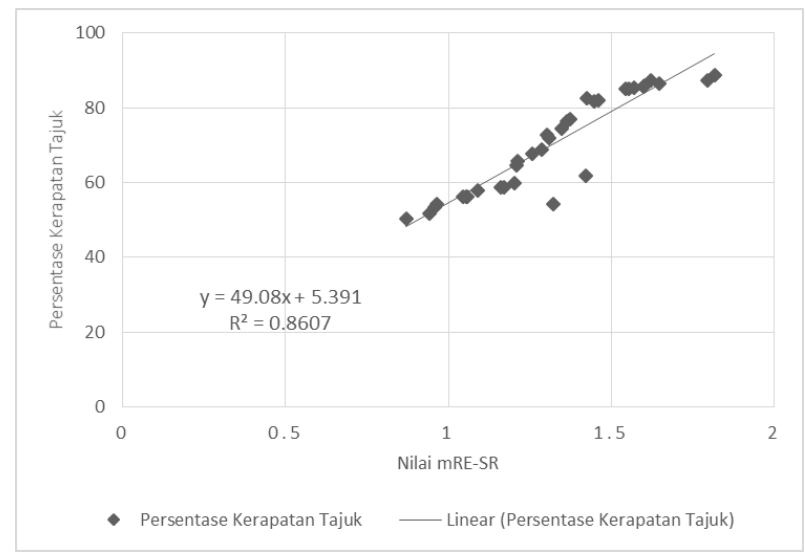

Gambar 5. Hasil regresi linier Indeks Vegetasi mRE-SR

Koefisien determinasi $\left(\mathrm{R}^{2}\right)$ yang dihasilkan dari model persamaan tersebut sebesar 0.8607 yang berarti bahwa sebanyak $86,07 \%$ variasi nilai kerapatan tajuk mangrove di lapangan dapat dijelaskan oleh nilai piksel dari indeks vegetasi mRE-SR. Nilai tersebut menunjukkan nilai indeks 
mRE-SR mampu menjelaskan dengan baik kerapatan tajuk di lapangan dibandingkan dengan indeks NDVI dan EVI. Uji RMSE menunjukkan penyimpangan nilai penduga kerapatan mangrove hasil dari model regresi yang dibangun adalah sebesar $\pm 4.9571 \%$. Nilai RMSE ini lebih kecil dari penyimpangan yang dihasilkan oleh indeks vegetasi NDVI dan EVI yang masing-masing sebesar $\pm 8.1508 \%$ dan \pm 7.8117 .

Indeks mRE-SR memiliki keunggulan dalam formulanya dengan menggunakan spektrum gelombang RED-Edge (705 nm) sebagai modifikasi dari indeks Simple Ratio. Hal tersebut dikarenakan panjang gelombang $705 \mathrm{~nm}$ dan $750 \mathrm{~nm}$ memiliki sensitivitas yang baik pada setiap klorofil vegetasi. $R E D$-Edge atau yang dikenal dengan band merah tepi diketahui lebih sensitif terhadap parameter biofisik vegetasi dibandingkan dengan band-band lainnya (Zhu et al., 2017). Hal tersebut sesuai dengan hasil dari penelitian Candra et al. (2016) yang menggunakan indeks mRE-SR dari citra satelit Worldview-2 yang menunjukkan indeks tersebut sebagai model terbaik dalam mengestimasi stok karbon mangrove di TAHURA Ngurah Rai. Dilihat dari nilai korelasi (r), koefisien determinasi $\left(\mathrm{R}^{2}\right)$ dan nilai RMSE pada penelitian ini, penggunaan indeks mRE-SR dalam mengestimasi kerapatan tajuk mangrove juga menunjukkan hasil yang baik dimana indeks ini mampu menjelaskan kerapatan tajuk mangrove lebih baik dilihat dibandingkan indeks vegetasi NDVI dan EVI. Oleh karena itu, model linier dari indeks mRE-SR dapat dikatakan sebagai model terbaik untuk estimasi kerapatan tajuk mangrove di TAHURA Ngurah Rai.

\subsection{Distribusi Spasial Kerapatan Tajuk Mangrove di TAHURA Ngurah Rai}

Hasil dari uji model linier menunjukkan indeks vegetasi mRE-SR adalah indeks terbaik untuk menjelaskan kerapatan tajuk mangrove di TAHURA Ngurah Rai. Model linier tersebut selanjutnya dipetakan untuk melihat distribusi atau sebaran spasial kerapatan tajuk mangrove (Gambar 6).

Peta distribusi spasial kerapatan tajuk yang tersaji pada Gambar 6 menunjukkan kategori kerapatan tajuk jarang dengan warna hijau muda mendominasi pola sebaran kerapatan tajuk di TAHURA Ngurah Rai bagian yang mengarah ke laut. Kategori kerapatan tajuk sedang yang

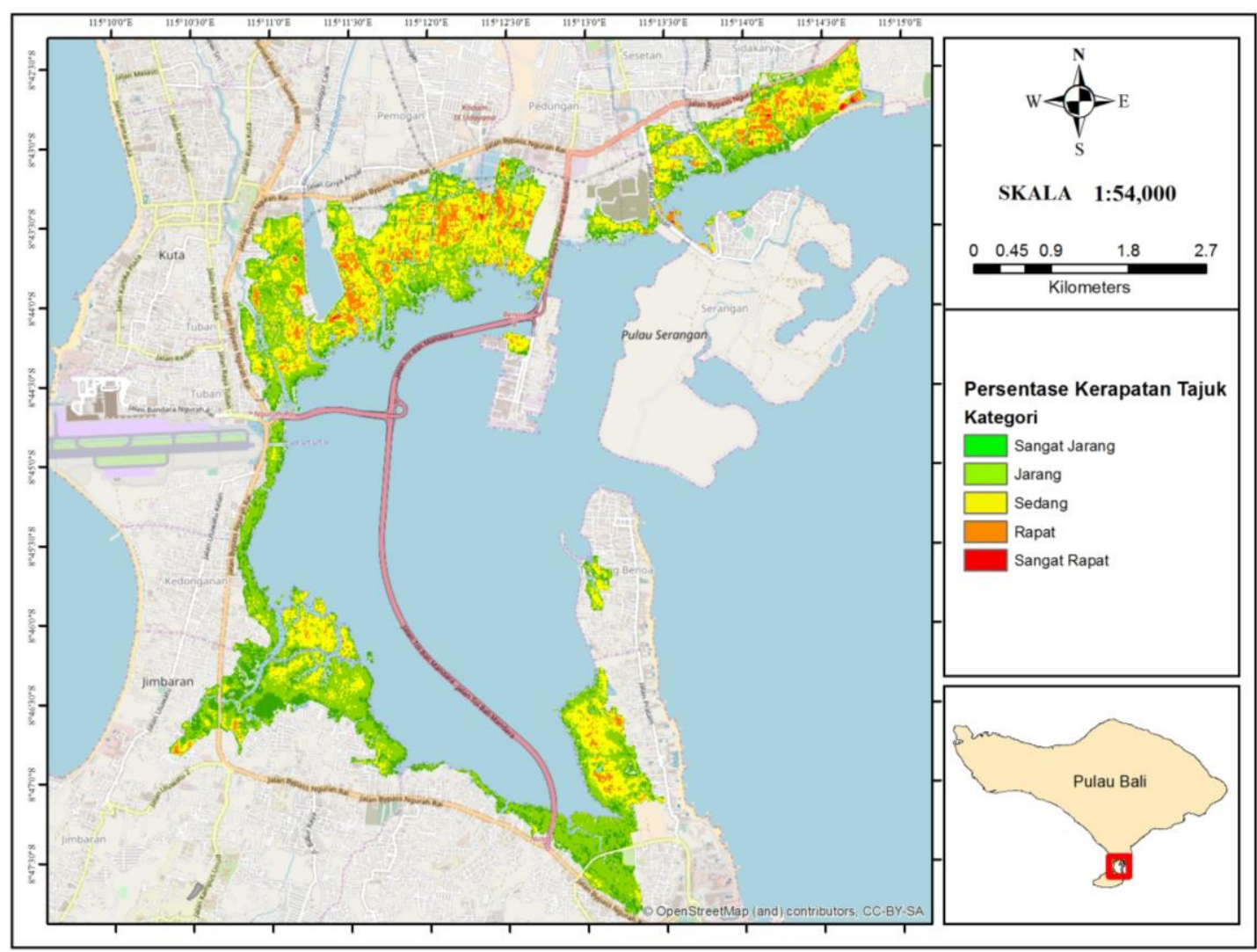

Gambar 6. Peta Distribusi Spasial Kerapatan Tajuk Mangrove di TAHURA Ngurah Rai 
Tabel 2

Hasil Perhitungan Luasan Setiap Kategori Kerapatan Tajuk Mangrove

\begin{tabular}{ccccc}
\hline $\begin{array}{c}\text { Kategori } \\
\text { Kerapatan Tajuk }\end{array}$ & $\begin{array}{c}\text { Persentase Kerapatan Tajuk } \\
\mathbf{( \% )}\end{array}$ & Jumlah Pixel & Luas Area $\left(\mathbf{m}^{2}\right)$ & Luas Area (Ha) \\
\hline Sangat Jarang & $33.09207171-45.02943722$ & 16878 & 1687800 & 168.78 \\
Jarang & $45.02943723-56.96680273$ & 40238 & 4023800 & 402.38 \\
Sedang & $56.96680274-68.90416824$ & 33300 & 3330000 & 333 \\
Rapat & $68.90416825-80.84153375$ & 9482 & 948200 & 94.82 \\
Sangat Rapat & $80.84153376-92.77889927$ & 324 & 32400 & 3.24 \\
Total & & 100222 & 10022200 & 1002.22 \\
\hline
\end{tabular}

ditunjukkan dengan warna kuning mendominasi setelah kategori jarang yang tersebar pada tegakan mangrove ke arah darat utamanya kawasan sekitar Mangrove Information Center (MIC). Karang dkk. (2017) mengatakan pertumbuhan mangrove cenderung dari darat menuju laut sehingga jumlah tegakan mangrove ke arah darat cenderung lebih banyak dan memiliki kerapatan yang lebih tinggi dibandingkan tegakan mangrove ke arah laut.

Hasil penelitian Nuarsa et al. (2005) menunjukkan luasan mangrove di TAHURA Ngurah Rai mengalami peningkatan sebesar 366.75 ha pada tahun 1994 hingga tahun 2003. Luas kawasan mangrove TAHURA Ngurah Rai menurut Dinas Kehutanan Provinsi Bali (2012) adalah 1.132 hektar sedangkan hasil dari perhitungan luas pada penelitian ini menggunakan citra Sentinel-2A sebesar 1002.22 hektar (Tabel 2). Hasil tersebut jika dibandingkan dengan hasil penelitian ini memiliki selisih 129.78 hektar. Selisih tersebut terjadi diduga karena adanya perbedaan metode pendekatan yang digunakan untuk mendeteksi mangrove. Faktor lain yang diduga menjadi penyebab berkurangnya luas hutan mangrove di TAHURA Ngurah Rai adalah adanya kerusakan atau degradasi oleh aktivitas manusia seperti untuk tempat pembuangan sampah, adanya bangunan jalan tol Nusa Dua Benoa-Ngurah Rai yang melewati hutan mangrove, pelebaran Bandara Ngurah Rai dan Pelabuhan Benoa (UPT TAHURA Ngurah Rai, 2010). Pencemaran dari sungai-sungai yang bermuara ke TAHURA Ngurah Rai juga diduga menjadi penyebab rusaknya ekosistem mangrove di kawasan tersebut. Penelitian Suteja dan Dirgayusa (2018) menunjukkan kawasan hutan mangrove TAHURA Ngurah Rai telah mengalami pencemaran yang berasal dari salah satu sungai yang bermuara ke kawasan mangrove tersebut dan berdampak kepada perubahan ekosistem mangrove disana. Penulis juga menemukan banyak sampah dari aktifitas manusia seperti bungkus makanan, gabus, dan sampah plastik disekitar akar mangrove saat pengambilan data lapangan. Menjaga kelestarian mangrove di TAHURA Ngurah rai penting untuk dilakukan mengingat pentingnya peran mangrove bagi biota disekitarnya dan kehidupan manusia.

\section{Simpulan}

Simpulan dari penelitian ini adalah indeks vegetasi mRE-SR pada citra Sentinel-2A menjadi indeks dengan akurasi terbaik untuk memetakan kerapatan tajuk mangrove di TAHURA Ngurah Rai dengan nilai korelasi (r) sebesar 0.9277, nilai koefisien determinasi $\left(\mathrm{R}^{2}\right)$ sebesar 0.8607 dan RMSE sebesar \pm 4.9571 dibandingkan dengan indeks vegetasi NDVI dan EVI.

Distribusi spasial kerapatan tajuk mangrove dari citra Sentinel-2A menunjukkan TAHURA Ngurah Rai memiliki hutan mangrove seluas 1002.22 Ha dengan kategori kerapatan tajuk sangat jarang seluas $168.78 \mathrm{Ha}$, kategori jarang seluas 402.38 Ha, kategori sedang seluas $333 \mathrm{Ha}$, kategori rapat seluas $94.82 \mathrm{Ha}$, dan kategori sangat rapat seluas $3.24 \mathrm{Ha}$.

\section{Daftar Pustaka}

Aji, B. J. P. S., \& Prasetyo, Y. (2017). Analisis Tingkat Produksi Padi dan Perhitungan Logistik Pangan Berdasarkan Metode Evi (Enhanced Vegetation Index) dan Ndvi (Normalized Difference Vegetation Index) Menggunakan Citra Sentinel-2 Tahun 2016 (Studi Kasus: Kabupaten Klaten, Jawa Tengah). Jurnal Geodesi Undip, 6(4), 263-273.

As-syakur, A. R., \& Adnyana, I. W. S. (2009). Analisis Indeks Vegetasi Menggunakan Citra ALOS/AVNIR-2 dan Sistem Informasi Geografi (SIG) Untuk Evaluasi Tata Ruang Kota Denpasar. Jurnal Bumi Lestari, 9(1), 111. 
BIG. (2014). Pedoman Teknis Pengumpulan Dan Pengolahan Data Geospasial Mangrove nomor 3 tahun 2014. Cibinong, Indonesia: Badan Informasi Geospasial.

Candra, E. D., Hartono, \& Wicaksono, P. (2016). Above Ground Carbon Stock Estimates of Mangrove Forest Using Worldview-2 Imagery in Teluk Benoa, Bali. In Proceedings of the International Conference of Indonesian Society for Remote Sensing (ICOIRS). Yogyakarta, Indonesia, 17-19 October 2016 (pp. 1-12)

Dharmawan, I. W. E., \& Pradmuji. (2014). Panduan Monitoring Status Kesehatan Komunitas Mangrove. Jakarta, Indonesia: COREMAP CTI LIPI.

Fensholt, R., Sandholt, I., \& Stisen, S. (2006). Evaluating MODIS, MERIS, and VEGETATION vegetation indices using in situ measurements in a semiarid environment. Journal IEEE Transactions on Geoscience and Remote Sensing, 44(7), 1774-1786.

Frananda, H., Hartono, H., \& Jatmiko, R. H. (2015). Komparasi Indeks Vegetasi Untuk Estimasi Stok Karbon Hutan Mangrove Kawasan Segoro Anak Pada Kawasan Taman Nasional Alas Purwo Banyuwangi, Jawa Timur. Jurnal Majalah Ilmiah Globe, 17(2), 113-123.

Giri, C., Ochieng, E., Tieszen, L. L., Zhu, Z., Singh, A., Loveland, T., Masek, J., \& Duke, N. (2011). Status and distribution of mangrove forests of the world using earth observation satellite data. Global Ecology and Biogeography, 20(1), 154-159.

Hatfield, J. L., \& Prueger, J. H. (2010). Value of using different vegetative indices to quantify agricultural crop characteristics at different growth stages under varying management practices. Journal of Remote Sensing, 2(2), 562-578.

Heumann, B. W. (2011). An object-based classification of mangroves using a hybrid decision tree-Support vector machine approach. Journal of Remote Sensing, 3(11), 2440-2460.

Hirata, Y., Tabuchi, R., Patanaponpaiboon, P., Poungparn, S., Yoneda, R., \& Fujioka, Y. (2014). Estimation of aboveground biomass in mangrove forests using highresolution satellite data. Journal of Forest Research, 19(1), 34-41.

Karang, I. W. G. A., Faiqoh, E., Indraiswari, I. G. A. A. M., \& Purba, A. P. (2015). Pemetaan Cadangan Karbon dan Biomassa Tegakan Tanaman Mangrove di TAHURA Ngurah Rai dengan Menggunakan Data Penginderaan Jauh. Laporan Kemajuan Hibah Unggulan Program Studi. Bali, Indonesia: Fakultas Kelautan dan Perikanan: Universitas Udayana.

Kawamuna, A., Suprayogi, A., \& Wijaya, A. P. (2017). Analisis Kesehatan Hutan Mangrove Berdasarkan Metode Klasifikasi NDVI Pada Citra Sentinel-2 (Studi Kasus: Teluk Pangpang Kabupaten Banyuwangi). Jurnal Geodesi Undip, 6(1), 277-284.

Kresnabayu, I. M. P., Putra, I. D. N. N., \& Suteja, Y. (2018). Kerapatan Hutan Mangrove Berbasis Data
Penginderaan Jauh di Estuari Perancak Kabupaten Jembrana-Bali. Journal of Marine and Aquatic Sciences, 4(1), 31-37.

Kustandiyo, H., Sukojo, B. M., \& Parwati, E. (2015). Studi Tingkat Kerapatan Mangrove Menggunakan Indeks Vegetasi. Jurnal Geoid, 9(2), 101-107.

Kusumaningrum, T. E., \& Sukojo, B. M. (2013). Analisa Kesehatan Mangrove Berdasarkan Nilai Normalized Difference Vegetation Index Menggunakan Citra ALOS AVNIR-2. Jurnal Geoid, 9(2), 142-149.

Mairing, J. P. (2017). Statistika Pendidikan, Konsep dan Penerapannya Menggunakan Minitab dan Microsoft Excel+ cd. Yogyakarta, Indonesia: Penerbit Andi.

Mitra, A., Sengupta, K., \& Banerjee, K. (2011). Standing biomass and carbon storage of above-ground structures in dominant mangrove trees in the Sundarbans. Journal of Forest Ecology and Management, 261(7), 1325-1335.

Muhsoni, F. F. (2009). Pemetaan Kerapatan Mangrove di Kepulauan Kangean Menggunakan Algoritma NDVI. Jurnal Ilmu Kelautan Universitas Trunojoyo, 10, 23-31.

Ni-Meister, W., Lee, S., Strahler, A. H., Woodcock, C. E., Schaaf, C., Yao, T., \& Blair, J. B. (2010). Assessing general relationships between aboveground biomass and vegetation structure parameters for improved carbon estimate from lidar remote sensing. Journal of Geophysical Research: Biogeosciences, 115(G2), 1-12.

Nuarsa, I. W., Adnyana, I. W. S., Sugimori, Y., Kanno, S., \& Nishio, F. (2005). Development of The New Algorithm for Mangrove Classification. International Journal of Remote Sensing and Earth Sciences (IJReSES), 2, 57-64.

Samsoedin, I., Dharmawan, I. W. S., \& Siregar, C. A. (2009). Potensi biomasa karbon hutan alam dan hutan bekas tebangan setelah 30 tahun di Hutan Penelitian Malinau, Kalimantan Timur. Jurnal Penelitian Hutan dan Konservasi Alam, 6(1), 47-56.

Sinaga, S. H., Suprayogi, A., \& Haniah, H. (2018). Analisis Ketersediaan Ruang Terbuka Hijau dengan Metode Normalized Difference Vegetation Index dan Soil Adjusted Vegetation Index Menggunakan Citra Satelit Sentinel-2a (Studi Kasus: Kabupaten Demak). Jurnal Geodesi Undip, 7(1), 202-211.

Sudiana, D., \& Diasmara, E. (2008). Analisis indeks vegetasi menggunakan data satelit NOAA/AVHRR dan TERRA/AQUA-MODIS. Dalam Seminar on Intelligent Technology and Its Applications 2008. Depok: Indonesia, 8 Mei 2008 (pp 423-428).

Sugianthi, N. L. M. A., Arthana, I. W., \& Adnyana, I. W. S. (2012). Monitoring Mangrove Area in Benoa Bay Using Landsat TM and ETM+ Data. Ecotrophic: Journal of Environmental Science, 2(1), 1-10.

Suteja, Y., \& Dirgayusa, I. G. N. P. (2018). Bioaccumulation and translocation of chromium on crabs and mangroves in Mati River estuary, Bali, 
Indonesia. Journal of Aquaculture, Aquarium, Conservation \& Legislation, 11(2), 469-475.

Suyadi, S., Ulumudin, Y. I., \& Vebriansyah, R. (2013). Indeks Vegetasi Dari Citra Satelit Alos Untuk Memperkirakan Cadangan Karbon Atas Permukaan Di Hutan Mangrove. Berita Biologi, 12(2), 249-258.

Utami, F. P., Prasetyo, Y., \& Sukmono, A. (2016). Analisis Spasial Perubahan Luasan Mangrove Akibat Pengaruh Limpasan Sedimentasi Tersuspensi Dengan Metode Penginderaan Jauh (Studi Kasus: Segara Anakan Kabupaten Cilacap, Jawa Tengah). Jurnal Geodesi Undip, 5(1), 305-315.
Wicaksono, P., Danoedoro, P., Hartono, \& Nehren, U. (2016). Mangrove biomass carbon stock mapping of the Karimunjawa Islands using multispectral remote sensing. International Journal of Remote Sensing, 37(1), 26-52.

Zhu, Y., Liu, K., Liu, L., Myint, S. W., Wang, S., Liu, H., \& $\mathrm{He}, \mathrm{Z}$. (2017). Exploring the Potential of WorldView-2 Red-Edge Band-Based Vegetation Indices for Estimation of Mangrove Leaf Area Index with Machine Learning Algorithms. Remote Sensing, 9(10), 1-20.

(C) 2019 by the authors; licensee Udayana University, Indonesia. This article is an open access article distributed under the terms and conditions of the Creative Commons Attribution license (http://creativecommons.org/licenses/by/3.0/). 